\title{
Economic effectiveness of the organization's economic activities
}

\author{
Anton Chepulaynis ${ }^{1,}{ }^{*}$, and Svetlana Boronenkova ${ }^{1}$ \\ Ural State University of Economics, 620144, 8 Marta Str., 62, Ekaterinburg, Russia
}

\begin{abstract}
The article examines the theoretical aspects of the economic effectiveness of the organization's economic activity, presents the author's definition of the concept. To reveal the essence of economic effectiveness, a systematization and classification of types of effectiveness are given. For each type of effectiveness, specific desired ratios and growth indicators (drivers) are indicated, which ensures the continuity and sustainable development of the business in the future.
\end{abstract}

\section{Introduction}

In the context of today's economic realities, it is necessary to pay due attention to the issues of maintaining the positive performance of economic activity.

Economic effectiveness is a multidimensional category that serves as the final and most important indicator of an enterprise's performance; it gives an integral characteristic of its activity and is the basis for its improvement. However, at present there are a number of interrelated problems in this direction. When disclosing the essence of economic effectiveness, one should not dwell only on financial results as the basis for economic performance. It is necessary to consider it comprehensively, including also the nonfinancial aspects. This opens up the opportunity to reveal the behavioural approach to the formation of the economic effectiveness of the organization's economic activity.

\section{The concept and essence of economic effectiveness}

Economic effectiveness is understood as a subjective assessment of the quality of changes in financial and non-financial parameters of economic activity, characterizing the economic potential and economic results of an economic entity, the level of its sustainable development and the ability to position itself and its product in the market.

Based on the proposed definition, an extended classification of economic performance can be presented (Fig. 1).

With this approach to defining the essence and typology of economic effectiveness, we come to the conclusion that effectiveness is a multivariate model that is subject to the influence of many factors of the internal and external environment of an economic entity,

${ }^{*}$ Corresponding author: anthonas@yandex.ru 
and its assessment is completely subjective, that is, it depends on the opinion (conclusion) of that or another subject.

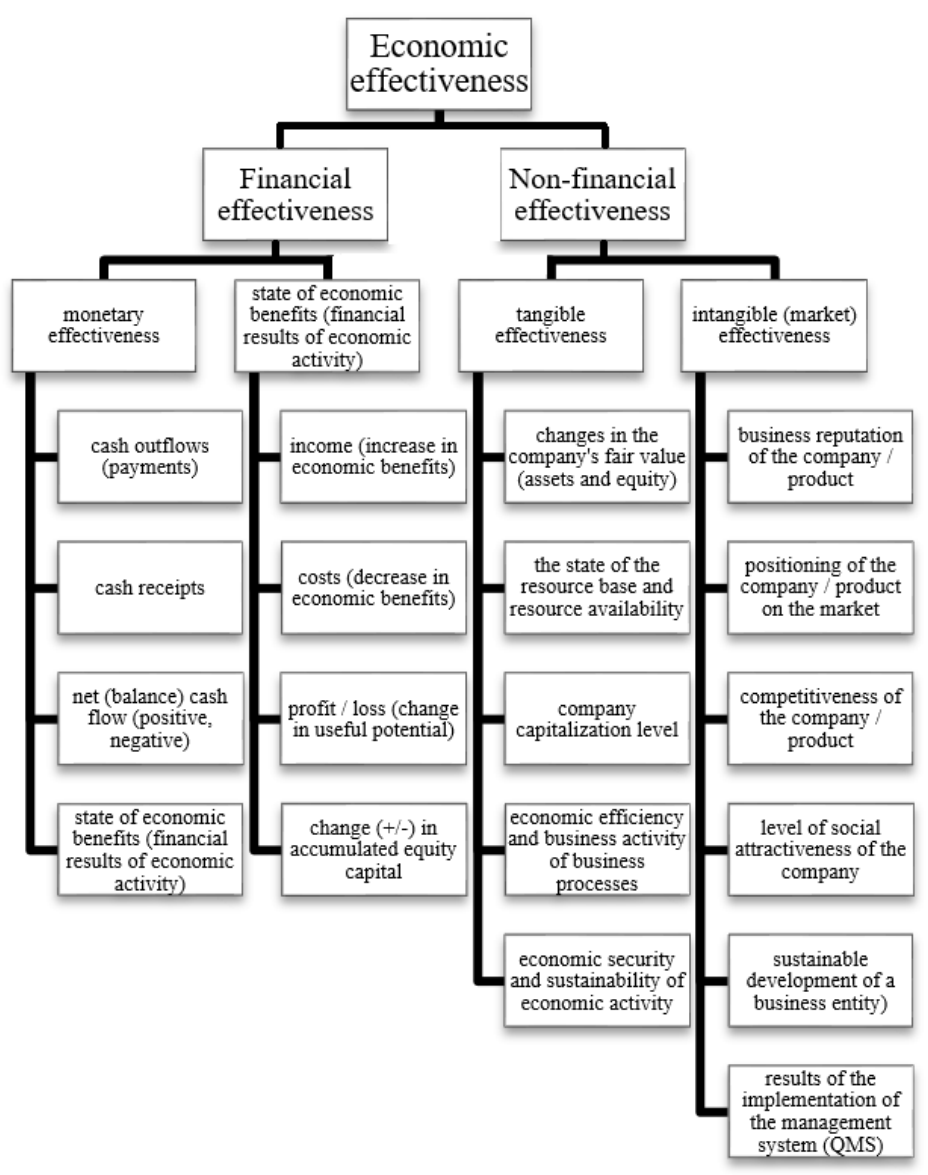

Fig. 1. Classification of economic effectiveness

When assessing the effectiveness of an individual process or activity as a whole, a conflict of interest may arise. One side may assess the performance as positive (or sustainable), while the other side may come to the conclusion that the results achieved are insufficient, thus, gives a negative assessment. Therefore, the role of the analyst in assessing performance is reduced to bringing the presented expert assessments to a "common denominator" the most objective assessment of these results by correlating the desired (normative) values and the obtained, planned and actual performance indicators.

The study showed that the most promising direction in solving the problem of objectivity in assessing economic performance is the development of a system of assessment indicators for comparing the achieved levels with objectively possible ones and taking into account specific economic conditions.

\section{Financial performance}


Financial effectiveness is determined by the ratio of income, expenses and cash flows. To assess the financial effectiveness of economic activities, it is necessary to evaluate the following ratios, which will serve as indicators of the quality of financial results.

Table 1. The ratio of the main indicators of financial performance

\begin{tabular}{|c|c|c|}
\hline Desired ratio & Symbol legend & Economic essence ratios \\
\hline \multicolumn{3}{|c|}{ Financial performance ratio } \\
\hline $\begin{array}{c}\mathrm{TpBp} \geq \\
\mathrm{TpC}_{3}\end{array}$ & $\begin{array}{l}B p-\text { net proceeds } \\
(2110) \\
C_{3}-\text { cost of sales } \\
(2120)\end{array}$ & $\begin{array}{l}\text { Outpacing of the growth rate of revenue over the cost } \\
\text { of products sold (goods, works, services) provides a } \\
\text { progressive increase in the marginality (profitability) of } \\
\text { the organization's production activities. Also, this ratio } \\
\text { has a positive effect on the financial performance of the } \\
\text { main activity of an economic entity. }\end{array}$ \\
\hline $\begin{array}{c}\mathrm{Tp} \mathrm{B} \Pi \geq \\
\mathrm{TpBp}\end{array}$ & $\begin{array}{l}B \Pi-\text { gross profit } \\
(2100)\end{array}$ & $\begin{array}{l}\text { Gross profit is the financial result of the organization's } \\
\text { production activities and is calculated as the difference } \\
\text { between income from ordinary activities from the sale } \\
\text { of products (goods, works and services) and the cost of } \\
\text { these items (full or truncated). Gross profit is margin } \\
\text { income. This relationship follows from the first one. Its } \\
\text { implementation indicates that the income received from } \\
\text { the main activity provides the formation of the marginal } \\
\text { income - the main factor of the break-even of the main } \\
\text { activity of the organization. }\end{array}$ \\
\hline $\begin{array}{c}\mathrm{TpC} \mathrm{C}_{3} \geq \mathrm{Tp}(\mathrm{Kp} \\
+\mathrm{Yp})\end{array}$ & $\begin{array}{l}\text { Kp - business } \\
\text { expenses }(2210) \\
\text { Yp - administrative } \\
\text { expenses }(2220)\end{array}$ & $\begin{array}{l}\text { This ratio characterizes the level of quality of the } \\
\text { organization's expenses, since the Cs indicator reflects } \\
\text { the variable part of the costs incurred and includes, as a } \\
\text { rule, variable costs; }(\mathrm{Cr}+\mathrm{Ur}) \text { - these are overhead } \\
\text { (indirect) costs and they, in turn, are represented by } \\
\text { fixed costs. If this ratio is not met, the marginality } \\
\text { condition will be violated and the company will } \\
\text { subsequently receive a negative financial result. }\end{array}$ \\
\hline $\begin{array}{c}\text { TpПp } \geq \\
\text { ТpBp }\end{array}$ & $\begin{array}{l}\text { Пр - profit from } \\
\text { sales (2200) }\end{array}$ & $\begin{array}{l}\text { Profit from sales is an indicator of financial } \\
\text { performance for the main activities of the organization, } \\
\text { which is the subject of its activity. This relationship is a } \\
\text { consequence of the fulfillment of the previous three } \\
\text { relationships. In case of violation of one of the previous } \\
\text { relationships. Its implementation characterizes the } \\
\text { growth of profitability of sales and, consequently, the } \\
\text { efficiency of the main activity of the organization. }\end{array}$ \\
\hline $\begin{array}{l}\text { ТрПр } \geq \\
\text { Тр ВП }\end{array}$ & $\begin{array}{l}B \Pi-\text { gross profit } \\
(2100) ; \\
\Pi p-\text { profit from } \\
\text { sales (2200) }\end{array}$ & $\begin{array}{l}\text { The fulfillment of the ratio of the growth rates of profit } \\
\text { from sales and gross profit testifies to the effective } \\
\text { management of costs in the organization and the growth } \\
\text { of profitability outstrips costs. This ratio is a } \\
\text { fundamental condition for breakeven production. }\end{array}$ \\
\hline $\begin{array}{l}\text { ТрПр } \geq \\
\text { ТрФР пр }\end{array}$ & $\begin{array}{l}\Phi \mathrm{P}_{\text {пр }}-\text { financial result } \\
\text { from other activities } \\
(2310+2320-2330 \\
+2340-2350)\end{array}$ & $\begin{array}{l}\text { The outstripping growth rates of profit from sales } \\
\text { (financial result from the main activity) over other } \\
\text { results indicates the effectiveness of the main activity } \\
\text { and the fact that it is the main driver of growth in the } \\
\text { effectiveness of the economic activity of the } \\
\text { organization }\end{array}$ \\
\hline $\begin{array}{c}\text { TpВp } \geq \\
\text { Tp (ПрД1 }+ \\
\left.\Pi p_{2}+\Pi_{1} Д_{3}\right)\end{array}$ & $\begin{array}{l}\text { ПрД} 1 ~-\text { income from } \\
\text { participation in other } \\
\text { organizations }(2310) ; \\
\text { ПрД } 2 \text { - interest }\end{array}$ & $\begin{array}{l}\text { Financial effectiveness should primarily be formed at } \\
\text { the expense of income from core activities (revenue), } \\
\text { which guarantees the quality of financial results. }\end{array}$ \\
\hline
\end{tabular}




\begin{tabular}{|c|c|c|}
\hline Desired ratio & Symbol legend & Economic essence ratios \\
\hline & $\begin{array}{l}\text { receivable }(2320) \\
\Pi_{p} Д_{3}-\text { other income } \\
(2340)\end{array}$ & \\
\hline $\begin{array}{c}\mathrm{Tp} \mathrm{C} \Pi \geq \\
\operatorname{Tp}\left(\Pi p P_{1}+\right. \\
{\left.\Pi p P_{2}\right)}^{2}\end{array}$ & $\begin{array}{l}\text { СП }- \text { full cost }(\mathrm{C} 3+ \\
\text { Кр }+ \text { Ур или. } 2120+ \\
2210+2220) \\
\text { ПрР } 1 \text { - interest } \\
\text { payable }(2330) ; \\
\text { ПрР } 2 \text { - other expenses } \\
(2350)\end{array}$ & $\begin{array}{l}\text { In terms of costs, financial performance should also be } \\
\text { supported by operating costs. If other expenses grow } \\
\text { faster than the joint venture, this indicates high costs for } \\
\text { other business processes not related to the subject of } \\
\text { management, it is necessary to revise the financial and } \\
\text { investment policy of the organization. }\end{array}$ \\
\hline $\begin{array}{c}\text { Тр Доходы } \geq \\
\text { Тр Расходы }\end{array}$ & $\begin{array}{l}\text { income }-2110+2310 \\
+2320+2340 \\
\text { costs }-2120+2210+ \\
2220+2330+2350\end{array}$ & $\begin{array}{l}\text { This is the main condition for obtaining a positive } \\
\text { financial result of the organization. Compliance with } \\
\text { this ratio is the basis for managing the financial } \\
\text { effectiveness of economic activities. }\end{array}$ \\
\hline $\begin{array}{l}\text { ТрПр } \geq \\
\text { Тр Пб }\end{array}$ & $\begin{array}{l}\text { Пб - profit before tax } \\
\text { (accounting profit, } \\
2300 \text { ) }\end{array}$ & $\begin{array}{l}\text { Accounting profit reflects the aggregate financial result } \\
\text { of the organization's economic activity before taxation } \\
\text { (excluding the tax burden factor). At the same time, in } \\
\text { order to characterize the quality of pre-tax profit, it is } \\
\text { necessary to fulfill this ratio, which guarantees its } \\
\text { formation at the expense of income and expenses for } \\
\text { the main type of activity, as the main drivers of } \\
\text { financial effectiveness. }\end{array}$ \\
\hline $\begin{array}{l}\text { Тр Пб } \geq \\
\text { Тр ТнП }\end{array}$ & $\begin{array}{l}\text { THП - current } \\
\text { income tax } \\
(2410)\end{array}$ & $\begin{array}{l}\text { Current income tax reflects the tax burden on the } \\
\text { financial result of the organization. The fulfillment of } \\
\text { this ratio indicates the implementation of tax planning } \\
\text { measures and optimization of the tax burden on } \\
\text { financial results at the enterprise. }\end{array}$ \\
\hline $\begin{array}{l}\text { ТрПч } \geq \\
\text { Тр Пб }\end{array}$ & $\begin{array}{l}\text { Пч - net profit } \\
\text { ( } 2400)\end{array}$ & $\begin{array}{l}\text { Net profit is the aggregate financial result of the } \\
\text { organization's economic activity, taking into account } \\
\text { the taxation factor. The fulfillment of this ratio } \\
\text { indicates a decrease in the tax burden on the financial } \\
\text { results of the organization and characterizes the } \\
\text { effectiveness of the tax policy of the organization. }\end{array}$ \\
\hline $\begin{array}{l}\text { ТрПч } \geq \\
\text { Тр СФР }\end{array}$ & $\begin{array}{l}\text { CФP - aggregate } \\
\text { financial result of the } \\
\text { period ( } 2500) \\
\text { BOA - fixed assets } \\
(1100)\end{array}$ & $\begin{array}{l}\text { The aggregate financial result of the period is formed at } \\
\text { the expense of net profit, as the aggregate financial } \\
\text { result, the result of the economic activity of the } \\
\text { organization, as well as the results of the external } \\
\text { environment (revaluation of the BOA value, change in } \\
\text { the value of property expressed in foreign currency, } \\
\text { etc.). If the organization itself directly affects the net } \\
\text { profit in the course of its activities, then the enterprise } \\
\text { cannot practically influence the results of the external } \\
\text { environment. Therefore, net profit should be the } \\
\text { leading factor in the formation of the } C \Phi P \text {. }\end{array}$ \\
\hline \multicolumn{3}{|r|}{ Cash flow status } \\
\hline $\begin{array}{l}\text { Tp cash } \\
\text { receipts current } \\
\text { activities } \geq \mathrm{Tp} \\
\text { cash expenses } \\
\text { current } \\
\text { activities } \\
\end{array}$ & $\begin{array}{l}\text { cash receipts current } \\
\text { activities }(4110) \\
\text { cash expenses } \\
\text { current activities } \\
(4120)\end{array}$ & $\begin{array}{l}\text { A higher growth rates of cash receipts from current } \\
\text { activities over cash expenses ensures the preservation } \\
\text { and increase of a positive balance of cash flows from } \\
\text { current activities, which ensures the efficiency of } \\
\text { current activities. }\end{array}$ \\
\hline $\begin{array}{l}\text { Tp cash } \\
\text { receipts } \\
\text { financial }\end{array}$ & $\begin{array}{l}\text { Cash receipts } \\
\text { (financial activities) } \\
(4210)\end{array}$ & $\begin{array}{l}\text { A higher growth rate of cash receipts from financial } \\
\text { activities over cash expenditures ensures the } \\
\text { preservation and increase of a positive balance of cash }\end{array}$ \\
\hline
\end{tabular}




\begin{tabular}{|c|c|c|}
\hline Desired ratio & Symbol legend & Economic essence ratios \\
\hline $\begin{array}{l}\text { activities } \geq \mathrm{Tp} \\
\text { cash expenses } \\
\text { financial } \\
\text { activities }\end{array}$ & $\begin{array}{l}\text { Cash expenses } \\
\text { (financial activities) } \\
\text { (4220) }\end{array}$ & $\begin{array}{l}\text { flows from financial activities and indicates an increase } \\
\text { in external financing and the creditworthiness of the } \\
\text { organization. }\end{array}$ \\
\hline $\begin{array}{c}\text { Tp Cash } \\
\text { receipts } \\
\text { investment } \\
\text { activities } \geq \mathrm{Tp} \\
\text { Cash expenses } \\
\text { investment } \\
\text { activities }\end{array}$ & $\begin{array}{l}\text { Cash receipts } \\
\text { (investment } \\
\text { activities) }(4310) \\
\text { Cash expenses } \\
\text { (investment } \\
\text { activities) (4320) }\end{array}$ & $\begin{array}{l}\text { A higher growth rate of cash receipts from investment } \\
\text { activities over cash expenditures ensures the } \\
\text { preservation and increase of the positive balance of } \\
\text { cash flows from investment activities and indicates, on } \\
\text { the one hand, the return on invested capital (funds } \\
\text { provided), and on the other hand, the sale of property } \\
\text { and financial instruments for ensuring current liquidity } \\
\text { and solvency. }\end{array}$ \\
\hline $\begin{array}{l}\text { Tp total cash } \\
\text { receipts } \geq \mathrm{Tp} \\
\text { Total cash } \\
\text { expenses }\end{array}$ & $\begin{array}{l}\text { total cash receipts } \\
(4110+4210+ \\
4310) \\
\text { Total cash expenses } \\
(4120+4220+ \\
4320)\end{array}$ & $\begin{array}{l}\text { The condition for maintaining and increasing the } \\
\text { positive total balance of cash flows is the excess of total } \\
\text { cash receipts over cash expenditures both in absolute } \\
\text { and relative terms. Violation of this ratio will adversely } \\
\text { affect the further solvency and slowdown of the } \\
\text { organization's business activity. }\end{array}$ \\
\hline $\begin{array}{l}\text { Tp cash } \\
\text { receipts current } \\
\text { activities } \geq \mathrm{Tp} \\
\text { Cash receipts } \\
\text { financial and } \\
\text { investment } \\
\text { activities }\end{array}$ & $\begin{array}{l}\text { cash receipts current } \\
\text { activities }(4110) \\
\text { Cash receipts } \\
\text { financial and } \\
\text { investment activities } \\
(4210+4310)\end{array}$ & $\begin{array}{l}\text { Cash receipts from current activities should grow faster } \\
\text { than receipts from other areas of activity, which ensures } \\
\text { financial independence and sufficiency of own funds } \\
\text { for carrying out economic activities (the ability to self- } \\
\text { finance). }\end{array}$ \\
\hline $\begin{array}{l}\text { Tp cash } \\
\text { expenses } \\
\text { current } \\
\text { activities } \geq \mathrm{Tp} \\
\text { Cash expenses } \\
\text { financial and } \\
\text { investment } \\
\text { activities }\end{array}$ & $\begin{array}{l}\text { cash expenses } \\
\text { (current activities) } \\
(4120) \\
\text { Cash expenses } \\
\text { (financial and } \\
\text { investment activities) } \\
(4220+4320)\end{array}$ & $\begin{array}{l}\text { Cash expenses for current activities should have a } \\
\text { higher growth rate in comparison with other areas of } \\
\text { spending, which indicates the direction of fixed funds } \\
\text { to core activities. }\end{array}$ \\
\hline $\begin{array}{l}\text { Tp Net cash } \\
\text { flow, current } \\
\text { activity } \geq \mathrm{Tp} \\
\text { Net cash flow, } \\
\text { financial and } \\
\text { investment } \\
\text { activities }\end{array}$ & $\begin{array}{l}\text { Net cash flow } \\
\text { (balance)(current } \\
\text { activity) (4100) } \\
\text { Net cash flow } \\
\text { (financial and } \\
\text { investment activities) } \\
(4200+4300)\end{array}$ & $\begin{array}{l}\text { The balance of cash flow from current activities should } \\
\text { grow at a faster pace compared to other types of } \\
\text { activities, since the basis of the total cash flow should } \\
\text { be cash receipts and expenses from current activities. }\end{array}$ \\
\hline
\end{tabular}

\section{Non-financial performance}

To assess non-financial effectiveness, it is necessary to apply a multivariate model, which incorporates both economic and non-economic parameters. This approach allows us to consider economic performance from various angles, including behavioural, on the basis of which the strategic aspects of performance management are revealed. Earlier, we divided non-financial effectiveness into tangible and intangible.

Tangible effectiveness is a qualitative assessment of changes in the economic potential of an economic entity, including the state of its assets and capital, economic security and sustainability under the influence of internal and external factors, the economic efficiency of business processes and their provision with the necessary resources. Thus, the tangible 
effectiveness is based on the state and dynamics of economic potential, its structure is shown in Fig. 2.

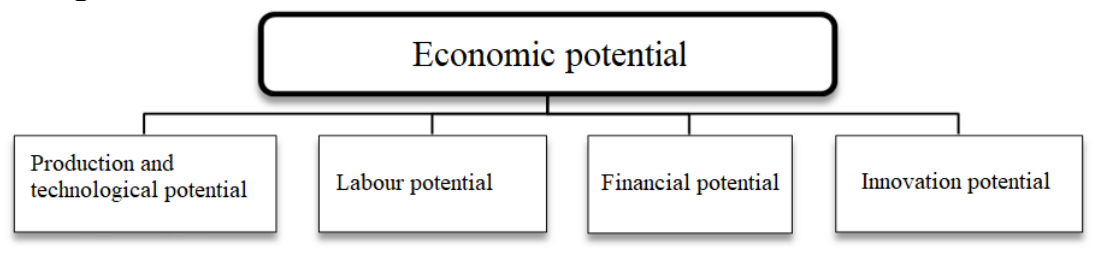

Fig. 2. The structure of economic potential

The production and technological potential is characterized by the state of the resource base, the provision of production processes with tools and objects of labour, the progressiveness of the technologies used and a high level of quality of all business processes at all stages of the company's product value chain. When describing tangible effectiveness on the basis of production and technological potential, the ultimate goal is seen in increasing efficiency and ensuring the continuity of all business processes at all stages of the value chain, which will contribute to the growth of economic potential.

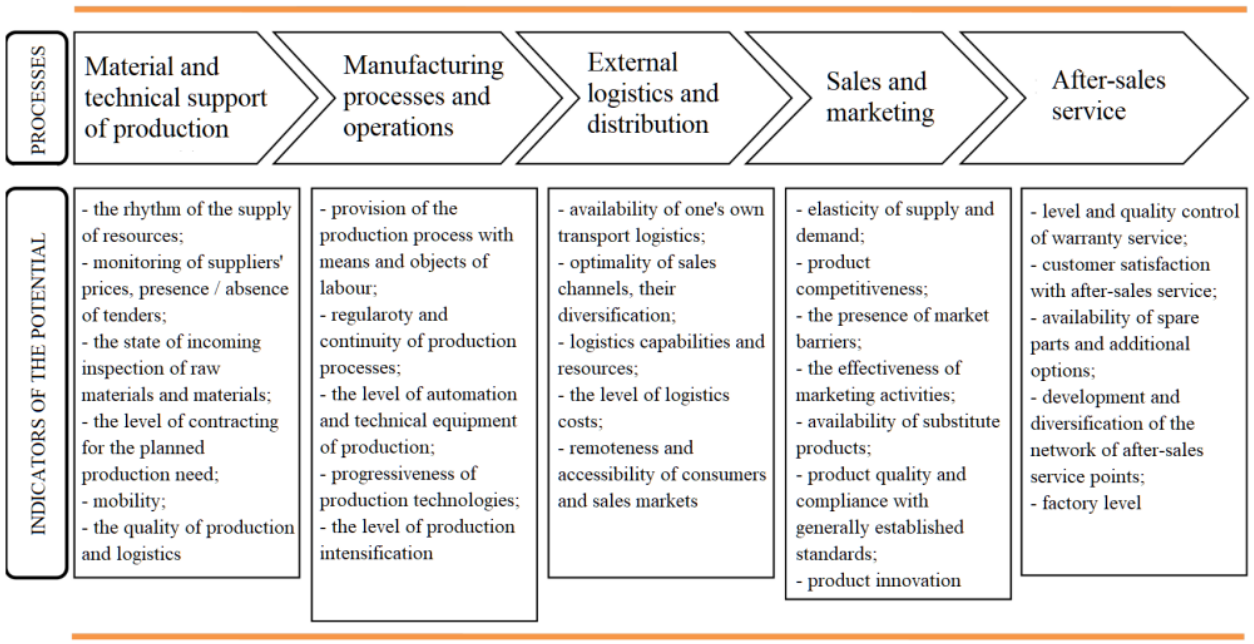

Fig. 3. Indicators of the growth of production and technological potential

The second important factor in the composition of economic potential is labour potential. With regard to economic effectiveness, labour potential is a qualitative assessment of cooperation and participation of workers in production and technological processes and operations, taking into account their psycho-physiological characteristics, intellectual level, professional knowledge and skills, and accumulated experience.

The growth of labour potential depends, on the one hand, on the possibility of participation of the employee (or all members of the enterprise) in socially useful activities as a specific production resource, on the other hand, on the qualitative indicators of labour resources, reflecting the degree of development of their abilities, suitability and readiness to perform works of a certain type and quality, attitude to work. Labour potential growth indicators are presented in Fig. 4. 


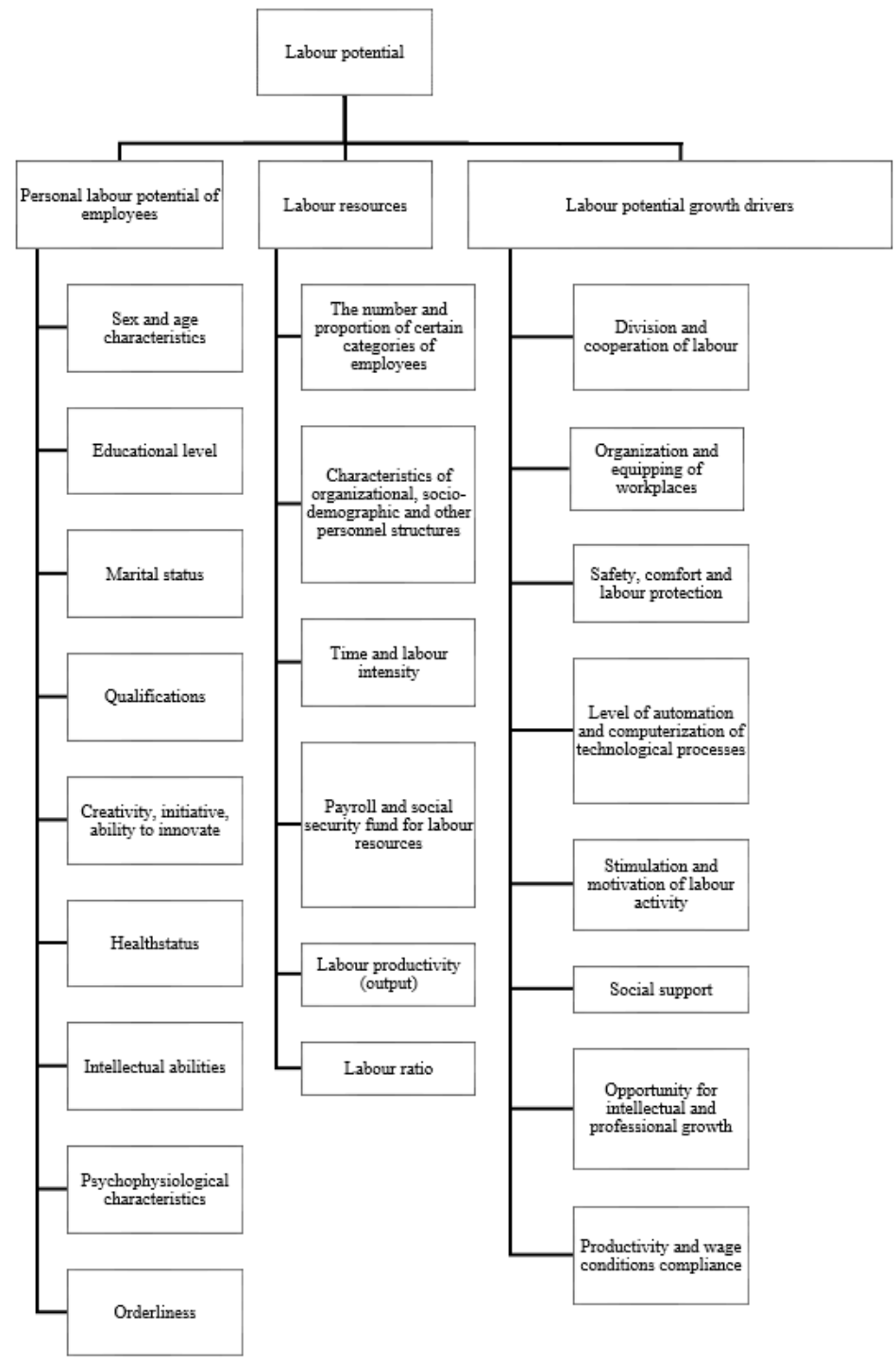

Fig. 4. Indicators of labour potential growth

The financial potential of the organization is an integral part of the economic potential and is characterized by the state of property (assets) and sources of financing of economic activity (liabilities). This element allows you to assess the economic security, financial stability, the value of the organization and the level of its capitalization. [2]

When considering the financial potential from the point of view of tangible effectiveness, it is necessary to take into account two aspects: the achieved level of accumulation or use of resources and the maximum possible prospective level. [9]

The achieved level is usually understood as the current financial condition of the enterprise at the considered date, taking into account the fair value of the enterprise, the type of financial stability, the level of liquidity and solvency, as well as indicators of business activity and efficiency of resource use.

The perspective aspect of the financial condition contains two sides: 
First, there are reserves and hidden opportunities that will improve the current financial condition, normalize financial stability and increase the business activity of the organization.

Second is creditworthiness, that is, the ability of an economic entity to attract additional financial resources and instruments to refinance current liabilities and finance its investment projects.

The intensive growth of economic potential and economic effectiveness is based on an increase in the level of science intensity of production processes, energy efficiency, rational and efficient use of resources and progressive technological development, which can only be realized through the introduction of innovations. The complex of innovations in these areas forms the innovative potential. Innovation potential permeates all components of economic potential and contributes to a synergistic effect in the development of an economic entity.

According to the "Oslo Guide. Recommendations for the Collection and Analysis of Data on Innovation" four types of innovation are distinguished: product innovation, marketing innovation, process innovation, organizational innovation (Fig. 5).

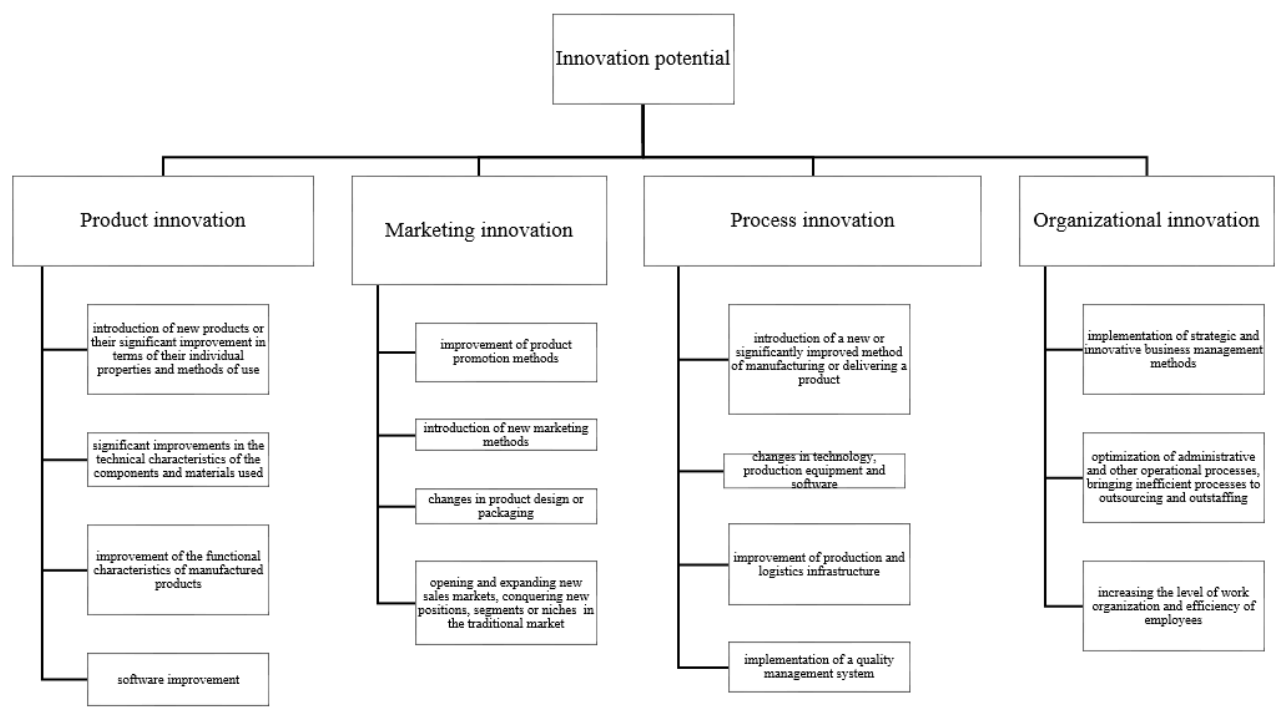

Fig. 5. Indicators of innovation potential growth

Formation of the developed innovative potential of the enterprise involves the implementation of all four directions. All innovations are based on science-intensive research, improving the efficiency and quality of all business processes, the development of machines and technology, which creates the basis for the innovative development of the company. Innovation is not limited to the material side and can be actively manifested in the improvement of methods, ways and processes of management and product promotion.

Market or intangible effectiveness directly depends on the behaviour of the company and its positioning in the market. Thus, intangible effectiveness is determined by the state of the company's market potential. The market potential is primarily influenced by external environmental factors; its development takes place under conditions of risk and uncertainty. The mission and strategy of the company play a leading role in realizing market potential. Intangible effectiveness directly depends on the effectiveness of the marketing policy and the depth of elaboration of the strategic management of the organization. The indicators of the growth of intangible effectiveness are presented in Fig. 6. 


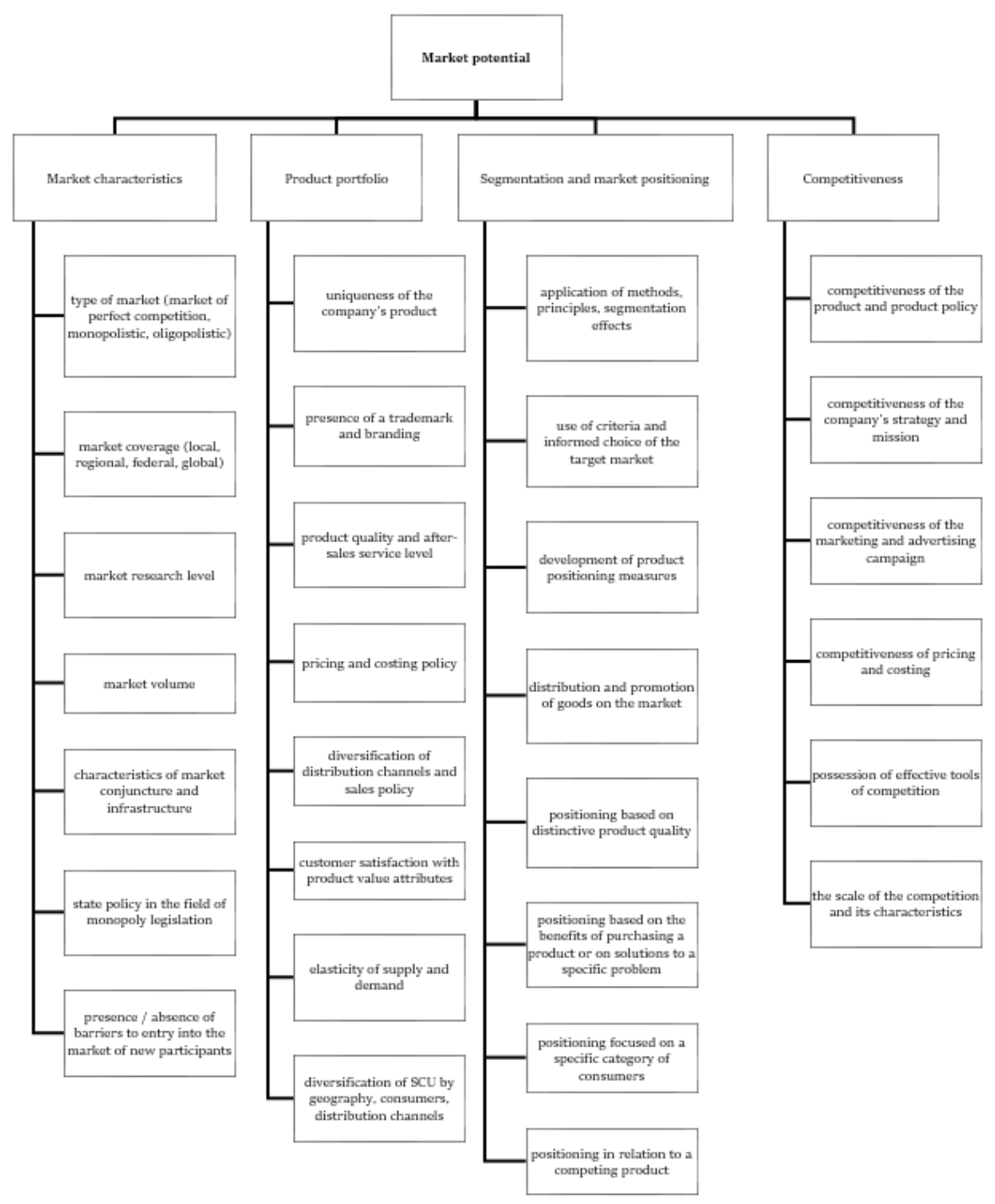

Fig. 6. Indicators of market potential growth

\section{Conclusions}

The formation of criteria for assessing economic performance, focused on a variety of subjects, requires the solution of a whole complex of problems of assessing not only the financial results of economic activity, but also the study of various kinds of factors affecting the change in the economic and market potential of the organization. [4]

The problems and approaches to the essence of economic performance outlined in this article allow us to conclude that it is necessary to create in each organization an integral system of analytical basic and derived characteristics of the performance of its activities, to identify among this set of dominant evaluation criteria, indicators and drivers available for perception by different subjects of business relationships, on the basis of which they will be able to make various current and strategic management decisions. 


\section{References}

1. S.A. Boronenkova, M.V. Melnik, A.V. Chepulyanis, Analysis of accounting (financial) statements study guide (2017)

2. I.A. Zhulega, Methodology of analysis of the financial condition of the enterprise: monograph (2006)

3. M.V. Zurin, Bulletin of the Plekhanov Russian University of Economics, 6 (2013)

4. N.S. Plaskova, Audit and financial analysis, 2 (2008)

5. N.S. Plaskova, Strategic and Current Economic Analysis: Monograp (2007)

6. E.V. Popov, Market potential of the enterprise: monograph (2002)

7. Oslo leadership. Recommendations for the collection and analysis of innovation data. 3rd ed. Joint publication by OECD and Eurostat. Organization for Economic Cooperation and Development Statistical Office of the European Communities (2010)

8. A.V. Chepulianis, Theoretical and methodological foundations of strategic accounting and cost analysis: monograph (2016)

9. T.G. Sheshukova, E.V. Kolesin, Improving the methodology for analyzing the economic potential of an economic entity: monograph (2013) 